\title{
Urgences
}

\section{Crime parfait}

\section{Jean Philippe}

Numéro 20, mai 1988

Appellation contrôlée

URI : https://id.erudit.org/iderudit/025475ar

DOI : https://doi.org/10.7202/025475ar

Aller au sommaire du numéro

Éditeur(s)

Urgences

ISSN

0226-9554 (imprimé)

1927-3924 (numérique)

Découvrir la revue

Citer ce document

Philippe, J. (1988). Crime parfait. Urgences, (20), 31-32.

https://doi.org/10.7202/025475ar

Ce document est protégé par la loi sur le droit d'auteur. L'utilisation des services d'Érudit (y compris la reproduction) est assujettie à sa politique d'utilisation que vous pouvez consulter en ligne.

https://apropos.erudit.org/fr/usagers/politique-dutilisation/
Cet article est diffusé et préservé par Érudit.

Érudit est un consortium interuniversitaire sans but lucratif composé de l’Université de Montréal, l'Université Laval et l'Université du Québec à Montréal. Il a pour mission la promotion et la valorisation de la recherche. https://www.erudit.org/fr/ 


\section{JEAN PHILIPPE \\ Crime parfait}

Le crime est une protestation généreuse.

Dostoïevski

1. À ce point incompréhensible de la douleur, il ne s'agit que de quelques heures dans une chose effacée, des terreurs ridicules, une tristesse de plus à éparpiller, des sentiments comme des poids à soutenir. La connivence est sans doute une forme dangereuse, une imposture dans le glissement boulimique des douceurs: tout s'enflamme et se déboîte en une matérialité si coincée dans cette Histoire. Et ces chercheurs d'explosion, et ces griffes très modernes, et ces visages que dénombrent les pressions...

2. Si, de jeu en artifice, ils s'abîment au défaut du regard, le désir n'aura de précision que dans une alarme accordée à cette donnée brutale d'un chatoiement, ma chair avalant leur destin jusque dans la phrase qui s'emmêle au défi de vider le signe secret de l'insensé. Il me faudra écrire l'horizon anonyme de la séduction, sa transaction aveugle, le vacarme immédiat de ses visions.

3. Cet âge du neutre qui file la vague sous le rose imprévisible des mains laisse le bord désaffecté des humeurs varier ses formes et ses intensités (les dimensions se moulent aux sourires amers de l'épaule adossée aux continents): une vision encrée dans la nuque court-circuite le séjour tendre des lignes infinitives, le retrait comme une pratique des plaisirs.

4. On retiendra la carte des épaules cuivrées comme la vacance d'une idée, son exécution hallucinée, sa part maudite. Partout, ailleurs, une avance pathétique affolle les aveux stellaires, détourne le feutré des atmosphères, conjure une histoire impossible. Mais qui dira ici la mort qui s'amuse dans les passions et la fuite des lignes? Il y a encore tant de désir dans la scène.

5. De l'éclair au faisceau, l'insouciance comme un luxe, un contre-chant, un spectacle frivole, comme un viol, une avant-garde, un art de faire, comme le lent appétit des désaffections, l'ivresse des éclipses, le sourire de l'Histoire. Que dire alors de cette heure de force quand la vague frémit et s'engage dans la courbe et pressent son éclat devant un corps impassible? Comment avouer l'arrogance d'un crime parfait? On ramassera au petit matin la grisaille, les circonstances et la ligne des mots et toute cette énergie que ne voleront plus les ongles avec l'insistance des passions. 
6. L'oeil quotidien déborde le rythme et les constellations, ajournant la dérive des infinis. Â l'angle des mémoires émues, les petits penseurs décrivent les ruses du sentiment sans se douter que ma chair baille et tourne de l'oeil. Ce n'est pas une promesse, encore moins la grande comédie des regrets. C'est le désir qui m'épargne, anonyme, le deuxième jour de mon intelligence. Ne plus hurler avec les loups. Pratiquer le désoeuvrement jusqu'à l'enthousiasme. Être ailleurs.

7. Comme un envol des siècles sur la pente des explosions, ces lignes détachables affichent les privilèges de l'atome et des surfaces sans me rejoindre jusqu' au point lumineux des splendeurs. Il y a bien sûr la scène et ces deux chercheurs que détaillent l'éblouissement et les vagues des parenthèses. S'allonge et se meurt le clin d'oeil, crime parfait. 